\title{
Antifeedant Activity of Anticopalic Acid Isolated from Vitex hemsleyi
}

\author{
Clarisa Villegas Gómez, Mariano Martínez-Vázquez*, and Baldomero Esquivel \\ Instituto de Química, Universidad Nacional Autónoma de México, Circuito Exterior, Cd. \\ Universitaria, Coyoacán 04510, México, D.F. Fax: +52 56162203. \\ E-mail: marvaz@servidor.unam.mx \\ * Author for correspondence and reprint requests \\ Z. Naturforsch. 64c, 502-508 (2009); received March 4/April 1, 2009 \\ The known labdane-type diterpenoids anticopalic acid (1) and $3 \beta$-hydroxyanticopalic acid \\ (2) were isolated from extracts of the aerial parts of Vitex hemsleyi Briq. (Labiatae). The \\ acid 1 showed an antifeedant, dose-dependent activity against Spodoptera frugiperda (J. E. \\ Smith) (Lepidoptera:Noctuidae). To our knowledge this is the first report on the antifeedant \\ activity of a labdane-type diterpene against $S$. frugiperda.
}

Key words: Vitex hemsleyi, Antifeedant Activity, Anticopalic Acid, Spodoptera frugiperda

\section{Introduction}

The genus Vitex (Labiatae) includes approximately 250 species which grow principally within tropical and subtropical regions (Harley et al., 2004; Walsingham and Atkins, 2006).

Several species of this genus have been studied by means of their putative biological properties. For instance, previous studies showed that some extracts of Vitex species possess activities such as antihypertensive (Ladeji et al., 1996), cytotoxic (Díaz et al., 2003), anti-inflammatory (Dharmasiri et al., 2003), bactericide (Kawazoe et al., 2001), antiallergic (Shin et al., 2000), fungicide (Sathiaoorthy et al., 2007), and antiviral (Woradulayapinij et al., 2005), as well as cause dermatological problems (Azhar-ul-Haq et al., 2006). They are also used to treat the premenstrual syndrome (Webster et al., 2006).

It is well known that a considerable number of species, besides their popular use as medicine in many countries, possess insecticidal activities; such is the case for some Vitex species. For example, it has been observed that $V$. hemsleyi is not attacked by insects in its habitat (Dirzo and Carrasco, 2002). In addition extracts from both $V$. trifolia and $V$. negundo showed insecticidal activities. Even more, $V$. trifolia was active against Aedes aegypti (Tawatsin et al., 2006), while V. negundo was active against Sitotroga cerealella (Krishnarajah et al., 1985).

Conversely, it is recognized that diterpenes, sesquiterpenes and procenes, among other secondary metabolites, are responsible for the antifeedant and insecticidal activities shown by several plants. It is worth noting that numerous groups of diterpenoids with antifeedant properties are clerodanes, isolated mainly from plants of the Labiatae family. Clerodin, ajugarins and jodrellin $\mathrm{A}$ are the best known members of this group (Paruch et al., 2001). Furthermore, epoxy derivatives of clerodane-type diterpenes such as 6-acetylteucjaponin showed antifeedant activity against Tenebrio spp., Leptinotarsa decemlineata and Spodoptera littoralis, supporting a similar neuroreceptor-mediated taste regulation for these insects (González-Coloma et al., 2005). On the other hand, studies on diterpene-type labdanes as antifeedant agents are scarce. For instance, 8(20),13-ent-labdadien-16,15olide-19-oic acid isolated from Eupatorium buniifolium $\mathrm{H}$ et $\mathrm{A}$ showed antifeedant activity against Tenebrio molitor L. (Cleoptera:Tenebrionidae) in a non-choice test (Cifuente et al., 2002). The antifeedant activity of trans-communic acid against Spodoptera litura at $20 \mu \mathrm{g} / \mathrm{disk}$ doses has also been reported; however, at $2 \mu \mathrm{g} /$ disk it reversed its activity. The reason for this change is ambiguous and it is still under study (Fukushima et al., 2001).

As a contribution to the chemistry and biological knowledge of Vitex species, now we wish to report the isolation of anticopalic acid (1) and $3 \beta$-hydroxyanticopalic acid (2) among other secondary metabolites from Vitex hemsleyi. The evaluation of $\mathbf{1}$ and $\mathbf{2}$ as antifeedant agents is also 
reported. It is worth to note that this is the first report on the antifeedant activity of labdane-type diterpenes against Spodoptera frugiperda.

\section{Material and Methods}

\section{Plant material}

Vitex hemsleyi Briq. (Labiatae) leaves were collected at Morelos, México. A voucher specimen (24979) was deposited at the herbarium of Centro de Educación Ambiental de la Sierra de Huautla, Universidad Autónoma del Estado de Morelos, México.

\section{General experimental procedures}

The melting points were determined in a Mel Temp II apparatus in open capillary tubes and are uncorrected. The optical rotations were measured at room temperature using a Perkin-Elmer 343 polarimeter (concentration in $\mathrm{g} / 100 \mathrm{~mL}$ ). The IR spectra were recorded using a FT-IR Bruker Tensor 27 spectrophotometer. The NMR spectra were determined on a Varian Unity 300 or Jeol Eclipse 300 NMR spectrometer, the chemical shifts $(\delta)$ are reported in ppm and $J$ values in Hz. Mass spectra were obtained with a Jeol JMS-SX 102A or JMS-AX 505 HA mass spectrometer. The identification and purity of compounds were monitored by TLC on silica gel. Flash chromatography was performed using silica gel 200-400 mesh.

\section{Extraction and isolation}

Dried and finely powdered leaves of $V$. hemsleyi $(620 \mathrm{~g})$ were extracted for $72 \mathrm{~h}$ with methanol $(15 \mathrm{~L})$ at room temperature. Elimination of the solvent by distillation at reduced pressure afforded a crude extract $(76.5 \mathrm{~g})$. The extract was dissolved in a mixture of methanol and water and extracted with hexane and dichloromethane successively. Elimination of the solvents by distillation at reduced pressure afforded the hexane $(33.3 \mathrm{~g})$ and the dichloromethane $(2.4 \mathrm{~g})$ extracts, respectively. Evaporation of the methanol/water mixture at reduced pressure afforded a polar extract.

Results of evaluation of the antifeedant activity showed that only the hexane and dichloromethane extract were active. In order to find the probable active compounds, these extracts were submitted to a chromatographic analysis and the secondary metabolites isolated were determined by spectroscopic methods.

The hexane extract was subjected to column chromatography on silica gel and eluted with hexane/AcOEt mixtures of increasing polarity, which yielded anticopalic acid (1) (3 g), 2-methyloctacosane (3) (42.3 mg), dehydroabietic acid methyl ester (4) (52 mg), 3 $\beta$-acetoxy-20(29)-lupene (5) $(15.6 \mathrm{mg}), \beta$-sitosterol (6) $(96 \mathrm{mg})$, gardenin D (7) $(3.0 \mathrm{mg})$, and gardenin B (8) $(82.5 \mathrm{mg})$ (Fig. 1).

Chromatography of the dichloromethane extract on silica gel gave a mixture of 4-hydroxybenzaldehyde and vanillin (9) $(5.4 \mathrm{mg})$ and $3 \beta$-hydroxyanticopalic acid (2) (638.6 mg) (Fig. 1).

Because the literature spectral data of anticopalic acid (1) and $3 \beta$-hydroxyanticopalic acid (2) are not complete we now report their ${ }^{13} \mathrm{C}$ NMR and MS data.

Anticopalic acid (1): Colourless oil. $-[\alpha]_{\mathrm{D}}=$ $+44.3^{\circ}$ (c 10, $\left.\mathrm{CHCl}_{3}\right) .-{ }^{1} \mathrm{H}$ NMR $(300 \mathrm{MHz}$, $\left.\mathrm{CDCl}_{3}\right): \delta=0.68(s, 3,20-\mathrm{H}), 0.80(s, 3,18-\mathrm{H})$, $0.87(s, 3,19-\mathrm{H}), 2.17(d, 3, J=1.2 \mathrm{~Hz}, 16-\mathrm{H}), 4.48$ (br s, 1, 17'-H), 4.85 (br s, 1, 17-H), 5.67 (qd, 1, $J=1.2 \mathrm{~Hz}, \mathrm{H}-14) .-{ }^{13} \mathrm{C}$ NMR $\left(75 \mathrm{MHz}, \mathrm{CDCl}_{3}\right)$ : $\delta=14.5(\mathrm{C}-20), 19.2(\mathrm{C}-18), 19.3(\mathrm{C}-16), 19.4(\mathrm{C}-$ 2), 21.5 (C-11), 21.7 (C-19), 24.4 (C-6), 38.3 (C-7), 39.1 (C-1), 40.1 (C-3 and C-10), 42.1 (C-12), 55.5 (C-5), 56.1 (C-9), 114.7 (C-14), 148.3 (C-8), 164.1 (C-13), 171.9 (C-15). - IR (film): $v_{\max }=3072,1687$, 1636, $886 \mathrm{~cm}^{-1}$. - EIMS: $\mathrm{m} / z=304\left[\mathrm{M}^{+}\right]$(27.5), 289 (78.5), 205 (45.0), 177 (42.7), 137 (100), 123 (63.0), 109 (62.0), 81 (72.0), 69 (42.0).

3 $\beta$-Hydroxyanticopalic acid (2): White amorphous solid; m.p. $140{ }^{\circ} \mathrm{C} .-[\alpha]_{\mathrm{D}}=+29.4^{\circ}(c 0.85$, $\left.\mathrm{CH}_{3} \mathrm{OH}\right) .-{ }^{1} \mathrm{H}$ NMR $\left(300 \mathrm{MHz}, \mathrm{CDCl}_{3}\right.$, DMSO$\left.\mathrm{d}_{6}\right): \delta=0.68(s, 3,20-\mathrm{H}), 0.76(s, 3,18-\mathrm{H}), 0.99(s$, 3, 19-H), $2.14(d, 3, J=1.17 \mathrm{~Hz}, 16-\mathrm{H}), 3.23(d d$, $1, J=11.43,4.71 \mathrm{~Hz}, 3-\mathrm{H}), 4.51$ (br s, 1, 17'-H), $4.85(b r s, 1,17-\mathrm{H}), 5.64(q d, 1, J=1.17 \mathrm{~Hz}, 14-$ $\mathrm{H}) .-{ }^{13} \mathrm{C}$ NMR $\left(75 \mathrm{MHz}, \mathrm{CDCl}_{3}-\mathrm{DMSO}-\mathrm{d}_{6}\right): \delta=$ 14.2 (C-20), 15.2 (C-18), 18.5 (C-16), 21.3 (C-11), 23.7 (C-6), 27.6 (C-2), 28.1 (C-19), 36.8 (C-1), 37.8 (C-7), 39.3 (C-4), 39.4 (C-10), 40.1 (C-12), 54.3 (C-5), 55.5 (C-9), 78.1 (C-3), 106.4 (C-17), 115.6 (C-14), 147.5 (C-8), 159.9 (C-13), 168.6 (C-15). IR (nujol): $v_{\max }=3353,3072,1693,1651,894 \mathrm{~cm}^{-1}$. - EIMS: $m / z=320\left[\mathrm{M}^{+}\right]$(12.5), 302 (40.1), 287 (40.2), 203 (37.1), 175 (21.0), 135 (100), 107 
(40.2). - HREIMS: $m / z=320.2349\left[\mathrm{M}^{+}\right]$; calcd. for $\mathrm{C}_{20} \mathrm{H}_{32} \mathrm{O}_{3}, 320.2351$.

\section{Esterification of $\mathbf{1}$}

The synthesis of anticopalic acid methyl ester (10) was carried out according to Arndt et al. (1946). Therefore, $20 \mathrm{~mL}$ of a solution of diazomethane in diethyl ether were added to a diethyl ether solution of anticopalic acid $(1 \mathrm{~g})$ at $5{ }^{\circ} \mathrm{C}$. The mixture was left for $1 \mathrm{~h}$, and the progress of the reaction was monitored by TLC. When the reaction was completed, the solvent was evaporated under low pressure, and the residue was purified on silica gel using a mixture of hexane and ethyl acetate (60:40) as eluent to give anticopalic acid methyl ester (10) in $78.2 \%$ yield.

Anticopalic acid methyl ester (10): Colourless oil. $-[\alpha]_{\mathrm{D}}=+25^{\circ}\left(\mathrm{CH}_{3} \mathrm{OH}\right) .-{ }^{1} \mathrm{H}$ NMR $(300 \mathrm{MHz}$, $\left.\mathrm{CDCl}_{3}\right): \delta=0.68(s, 3,20-\mathrm{H}), 0.80(s, 3,18-\mathrm{H}), 0.87$ $(s, 3,19-\mathrm{H}), 2.17(d, 3, J=1.2 \mathrm{~Hz}, 16-\mathrm{H}), 4.49$ (br s, 1,17'-H), 4.84 (br s, 1, 17-H), $5.65(q d, 1, J=1.2 \mathrm{~Hz}$, 14-H), $3.69\left(s, 3,-\mathrm{OCH}_{3}\right) .-{ }^{13} \mathrm{C}$ NMR $(75 \mathrm{MHz}$, $\left.\mathrm{CDCl}_{3}\right): \delta=14.4(\mathrm{C}-20), 18.9(\mathrm{C}-16), 21.7(\mathrm{C}-18)$, 33.6 (C-19), 50.6 (C-21), 106.3 (C-17), 114.9 (C14), 148.3 (C-8), 161.2 (C-13), 167.3 (C-15). - IR (film): $v_{\max }=1720,1647,888 \mathrm{~cm}^{-1}$. EIMS: $\mathrm{m} / z=$ 319 [M+1] (58.0), 303 (93.1), 287 (33.5), 205 (55.5), 137 (100), 114 (95.0), 95 (77.2).

\section{Epoxidation of $\mathbf{1 0}$}

A dry solution of $m$-chloroperbenzoic acid $(108.3 \mathrm{mg})$ in dicholoromethane $(10 \mathrm{~mL})$ was added dropwise to a cooled $\left(0{ }^{\circ} \mathrm{C}\right)$ and stirred solution of $\mathbf{1 0}(200 \mathrm{mg})$ in dichloromethane $(10 \mathrm{~mL})$. The mixture was stirred for $24 \mathrm{~h}$ at room temperature. The reaction was monitored by TLC. When the reaction was completed, the solvent was evaporated under reduced pressure at room temperature, and the crude compound was purified on silica gel using a mixture of hexane and ethyl acetate (90:10) as eluent to give $8,17 \beta$-epoxyanticopalic acid methyl ester (11) in $85.7 \%$ yield.

8,17 $\beta$-Epoxyanticopalic acid methyl ester (11): Colourless oil. $-{ }^{1} \mathrm{H}$ NMR $\left(300 \mathrm{MHz}, \mathrm{CDCl}_{3}\right): \delta=$ $0.80(s, 1,20-\mathrm{H}), 0.89(s, 1,19-\mathrm{H}), 0.82(s, 1,18-$ $\mathrm{H}), 2.12(d, 3, J=1.7 \mathrm{~Hz}, 16-\mathrm{H}), 2.50(d, 1, J=$ $4.11 \mathrm{~Hz}, 17-\mathrm{H}), 2.74\left(d d, 1, J=4.11,1.7 \mathrm{~Hz}, 17^{\prime}-\mathrm{H}\right)$, $3.68\left(s, 3,-\mathrm{OCH}_{3}\right), 5.65(q d, 1, J=1.7 \mathrm{~Hz}, 14-\mathrm{H})$. - IR (film): $v_{\max }=1719,1647,1224 \mathrm{~cm}^{-1}$. - EIMS: $m / z=334\left[\mathrm{M}^{+}\right]$(5.0), 289 (15.0), 205 (27.0), 177
(53.5), 109 (70.0), 95 (98.0), 69 (100), 41 (86.5), 28 (59.0).

\section{Oxidation of $\mathbf{1 0}$}

The oxidation of $\mathbf{1 0}$ was accomplished according to the method described by Umbreit and Sharpless (1977). $16.3 \mathrm{mg}(0.05 \mathrm{~mol})$ of $\mathrm{SeO}_{2}$ were dissolved in $1 \mathrm{~mL}$ of dichloromethane. The solution was stirred, and $65 \mu \mathrm{L}(0.2 \mathrm{~mol})$ of tert-butylhydroperoxide were added to the solution. The mixture was stirred for $30 \mathrm{~min}$ at $5{ }^{\circ} \mathrm{C}$, and then $30.4 \mathrm{mg}(0.1 \mathrm{~mol})$ of $\mathbf{1 0}$, previously dissolved in $1 \mathrm{~mL}$ of dichloromethane, were added. The mixture was stirred for $48 \mathrm{~h}$ at $25^{\circ} \mathrm{C}$. Finally, the solution was evaporated in vacuo and the reaction mixture was purified by column chromatography to give $7 \alpha$-hydroxyanticopalic acid methyl ester (12) in $54.8 \%$ yield.

$7 \alpha$-Hydroxyanticopalic acid methyl ester (12): Colourless oil. $-{ }^{1} \mathrm{H}$ NMR $\left(500 \mathrm{MHz}, \mathrm{CDCl}_{3}\right): \delta=$ $0.66(s, 1,20-\mathrm{H}), 0.80(s, 1,18-\mathrm{H}), 0.88(s, 1,19-\mathrm{H})$, $2.10(\mathrm{br} d d, 1, J=1.5,11.0 \mathrm{~Hz}, 9-\mathrm{H}), 2.16(d, 3, J=$ $1.5 \mathrm{~Hz}, 16-\mathrm{H}), 3.68\left(s, 3,-\mathrm{OCH}_{3}\right), 4.38(d d d, 1, J=$ 3.0, $5.5 \mathrm{~Hz}, 7-\mathrm{H}), 4.62\left(\right.$ br t $\left., 1,17_{\mathrm{b}}-\mathrm{H}\right), 5.07$ (br t, 1, $17 \mathrm{a}-\mathrm{H}), 5.65(q d, 1, J=1.0 \mathrm{~Hz} .14-\mathrm{H}) .-{ }^{13} \mathrm{C} \mathrm{NMR}$ $\left(125 \mathrm{MHz}, \mathrm{CDCl}_{3}\right): \delta=38.7(\mathrm{C}-1), 19.3(\mathrm{C}-2), 42.0$ (C-3), 39.8 (C-4), 47.6 (C-5), 30.9 (C-6), 74.0 (C7), 149.4 (C-8), 50.2 (C-9), 33.1 (C-10), 21.0 (C11), 39.3 (C-12), 160.7 (C-13), 115.0 (C-14), 167.2 (C-15), 18.8 (C-16), 109.6 (C-17), 21.5 (C-18), 33.2 (C-19), 13.4 (C-20), 50.7 (C.21). - IR (film): $v_{\max }=$ 3471, 1719, 1647, $862 \mathrm{~cm}^{-1}$. EIMS: $\mathrm{m} / z=334\left[\mathrm{M}^{+}\right]$ (5.0), 317 (5.0), 221 (29.0), 203 (40.0), 123 (100), 114 (66.5), 82 (83.0), 55 (49.0), 41 (38.5).

\section{8,17 $\beta$-Epoxyanticopalic acid (13)}

The epoxide derivative of anticopalic acid was obtained following the same procedure used for the synthesis of compound $\mathbf{1 1}$.

8,17 $\beta$-Epoxyanticopalic acid (13): Colourless oil. - ${ }^{1} \mathrm{H}$ NMR $\left(300 \mathrm{MHz}, \mathrm{CDCl}_{3}\right): \delta=0.81(s, 1$, 20-H), $0.83(s, 1,18-\mathrm{H}), 0.90(s, 1,19-\mathrm{H}), 2.13(d$, $3, J=1.2 \mathrm{~Hz}, 16-\mathrm{H}), 2.50(d, 1, J=4.2 \mathrm{~Hz}, 17-\mathrm{H})$, $2.75\left(d d, 1, J=4.5,1.8 \mathrm{~Hz}, 17^{\prime}-\mathrm{H}\right), 5.67(q d, 1, J=$ $0.9 \mathrm{~Hz}, 14-\mathrm{H})$. - IR (film): $v_{\max }=2945,1689,1253$, $838 \mathrm{~cm}^{-1}$. - EIMS: $m / z=320\left[\mathrm{M}^{+}\right]$(4.0), $302(15.0)$, 275 (28.0), 205 (45.0), 177 (54.5), 149 (67.5), 137 (96.0), 95 (98.0), 69 (100), 55 (63.0), 41 (68.5). 


\section{7 $\alpha$-Hydroxyanticopalic acid (14)}

The oxide derivative of anticopalic acid was obtained following the same procedure used for the synthesis of compound $\mathbf{1 2}$.

7 $\alpha$-Hydroxyanticopalic acid (14): Colourless oil. $-{ }^{1} \mathrm{H}$ NMR $\left(300 \mathrm{MHz}, \mathrm{CDCl}_{3}\right): \delta=0.66(s, 1$, 20-H), $0.80(s, 1,18-\mathrm{H}), 0.88(s, 1,19-\mathrm{H}), 2.16(d$, $3, J=0.6 \mathrm{~Hz}, 16-\mathrm{H}), 4.39(t, 1,7-\mathrm{H}), 4.63$ (br s, 1 , 17'-H), 5.08 (br s, 1, 17-H), $6.68(d, 1, J=0.6 \mathrm{~Hz}$, 14-H). - IR (film): $v_{\max }=3345,3078,1691,1642$, $868 \mathrm{~cm}^{-1}$. - EIMS: $m / z=320\left[\mathrm{M}^{+}\right](3.0), 302(14.0)$, 287 (17.5), 221 (27.0), 203 (35.0), 149 (75.0), 123 (100), 109 (32.5), 82 (52.0), 69 (48.5).

\section{Insect rearing}

Spodoptera frugiperda (Lepidoptera:Noctuidae) larvae were reared on artificial diet (Céspedes et al., 2000) at $(27 \pm 1){ }^{\circ} \mathrm{C},>70 \%$ relative humidity, with a photoperiod of $16 \mathrm{~h}: 8 \mathrm{~h}$ light:dark in a growth chamber.

\section{Insect bioassay}

The bioassay was conducted by a choice method (choice feeding assay). These experiments were conducted with sixth-instar (L-6) S. frugiperda larvae. Spinaceae oleraceae leaf disks were treated on the upper surface with $10 \mu \mathrm{L}$ of the test compound. Two treated and two control disks were placed on five agar-coated Petri dishes with two insects ( $S$. frugiperda), which were allowed to feed under the conditions described above (Mazoir et al., 2008). Each experiment was repeated three times. Feeding was terminated after the consumption of $75 \%$ of the control or treated disk. Feeding inhibition (FI) was calculated as \% FI $=[1$ - (T/C)] $\cdot 100$, where $\mathrm{T}$ and $\mathrm{C}$ are the consumption of treated and control leaf disks, respectively (Reina et al., 2001). Compounds with an FI value $>50 \%$ were tested in a dose-response experiment to calculate their relative potency $\left(\mathrm{EC}_{50}\right.$ values, the effective dose for $50 \%$ of feeding inhibition); this was determined from linear regression analysis ( $\%$ FI on log dose).

\section{Results and Discussion}

The chromatographic analyses of the hexane and dichloromethane extracts of aerial parts of $V$. hemsleyi led to the isolation of anticopalic acid (1) and 3 $\beta$-hydroxyanticopalic acid (2), respec-

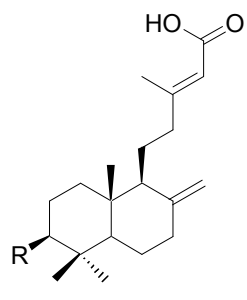

$1 \mathrm{R}=\mathrm{H}$ $2 \mathrm{R}=\mathrm{OH}$

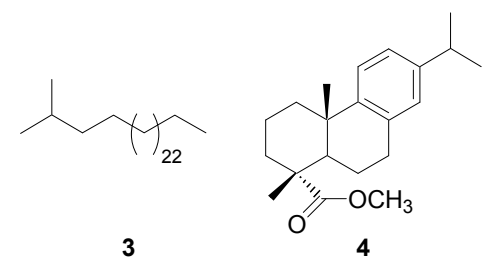

3

4

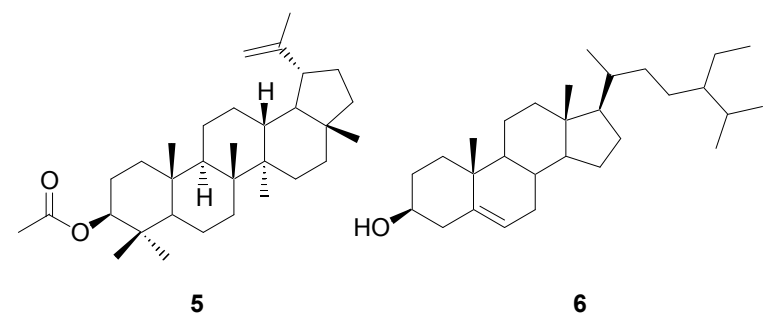<smiles>COc1cc(C=O)ccc1O</smiles>

$7 \mathrm{R}=\mathrm{OH}$

$8 \mathrm{R}=\mathrm{H}$

9

Fig. 1. Chemical structures of the secondary metabolites isolated from extracts of Vitex hemsleyi.

tively (Fig. 1). Curiously $\mathbf{1}$ and $\mathbf{2}$ have been previously isolated from Pinus monticola and P. strobus (Pinaceae) (Zinkel and Spalding, 1972; Zinkel and Magee, 1987). Since there is no taxonomic relationship between the genera Vitex and Pinus, the presence of $\mathbf{1}$ and $\mathbf{2}$ in both genera constitutes a chemical coincidence (Seaman, 1982).

Previous studies showed that the presence of diverse functional groups like epoxy, halohydrin, furanyl, or hydroxy groups is a common structural feature for a number of bioactive molecules (Gebbinck et al., 2002). Taking this into account and in order to establish a structure-activity relationship, we decided to synthesize some derivatives (Fig. 2), by chemical means, of the active anticopalic acid (1) and evaluate their antifeedant activity.

The conversions were focused mainly on the positions $7,8-17$ and 15 by several reactions. 


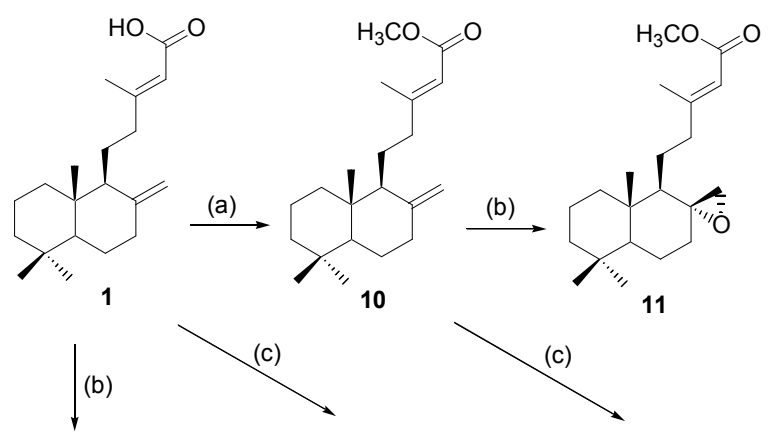

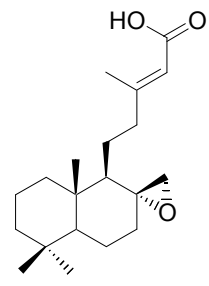

13

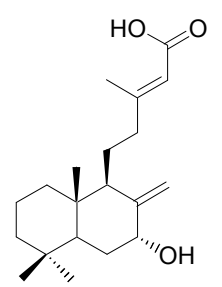

14

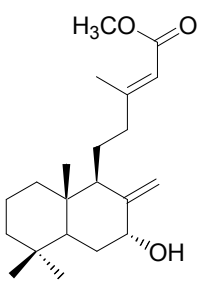

12
Fig. 2. Scheme of the synthesis of anticopalic acid derivatives. (a) Diazomethane, diethyl ether. (b) $m$-Chloroperbenzoic acid, $\mathrm{CH}_{2} \mathrm{Cl}_{2}$. (c) $\mathrm{SeO}_{2}$, tert-butylhydroperoxide, $\mathrm{CH}_{2} \mathrm{Cl}_{2}$.

The experimental conditions to obtain the derivatives 10-14 from $\mathbf{1}$ are outlined in Fig. 2.

Treatment of $\mathbf{1}$ with diazomethane in diethyl ether afforded the expected anticopalic acid methyl ester (10). This compound was previously isolated from Agathis lanceolata resin (Manh et al., 1983), Pinus strobus (Zinkel and Magee, 1987), and Trachylobium verrucosum resin (Hugel et al., 1996). The physical and spectroscopic data of $\mathbf{1 0}$ were consistent with those previously reported.

Treatment of $\mathbf{1 0}$ with $m$-chloroperbenzoic acid in dichloromethane gave $8,17 \beta$-epoxyanticopalic acid methyl ester (11). This transformation was easily confirmed by the inspection of the ${ }^{1} \mathrm{H}$ NMR spectrum of 11, where the lack of the signals assigned to the protons of an exocyclic double bound and the presence of protons of an epoxy group as a doublet at $\delta 2.50(J=4.11 \mathrm{~Hz})$ and an AB system at $\delta 2.74(J=4.11,1.7 \mathrm{~Hz})$, respectively, are worth to be noted. The rest of the signals of the ${ }^{1} \mathrm{H}$ NMR spectrum, as well as the MS spectrum, are in full agreement with the proposed structure (see Materials and Methods).

The reaction of $\mathbf{1 0}$ with selenium dioxide and tert-butylhydroperoxide in dichloromethane gave $7 \alpha$-hydroxyanticopalic acid methyl ester (12). The
Table I. Antifeedant effects ( $\%$ FI \pm S.E.) of compounds $\mathbf{1 , 2}$ and $10-14$ against $S$. frugiperda larvae.

\begin{tabular}{lc}
\hline Compound & \% FI $^{\mathrm{a}}$ \\
\hline $\mathbf{1}$ & $81.70 \pm 2.8^{*, \mathrm{~b}}$ \\
$\mathbf{2}$ & $3.53 \pm 7.3$ \\
$\mathbf{1 0}$ & $-11.57 \pm 8.8$ \\
$\mathbf{1 1}$ & $19.04 \pm 2.0$ \\
$\mathbf{1 2}$ & $29.68 \pm 8.0$ \\
$\mathbf{1 3}$ & $5.23 \pm 2.4$ \\
$\mathbf{1 4}$ & $-3.22 \pm 3.7$ \\
\hline
\end{tabular}

a $\% \mathrm{FI}=[1-(\mathrm{T} / \mathrm{C})] \cdot 100$, where $\mathrm{T}$ and $\mathrm{C}$ are the consumed leaf area of treated and control leaf disks, respectively, represented as mean values \pm standard error.

b $\quad \mathrm{EC}_{50}=90.6(83.6,98.1)$. Effective antifeedant dose $\left(\mathrm{EC}_{50}\right)$ and $95 \%$ confidence limits (lower, upper).

* $p<0.05$, Wilcoxon paired-rank test (Moreno-Osorio et al., 2008).

${ }^{1} \mathrm{H}$ NMR spectrum of $\mathbf{1 2}$ showed the presence of a hydroxy group in $\mathrm{C}-7$ position (Fig. 2) $[\delta 4.38$ $(d d d, J=3.0,5.5 \mathrm{~Hz})]$, as well as a proton in C-9 position $[\delta 2.10(b r d d, J=1.5 \mathrm{~Hz})]$. The ${ }^{13} \mathrm{C}$ NMR spectrum of 12 showed the C-7 and C-9 carbon atoms at $\delta 74.0$ and $50.2 \mathrm{ppm}$, respectively. These structural features were confirmed by the assistance of COSY, NOESY, HMBC and HMQC experiments.

The derivatives $\mathbf{1 3}$ and $\mathbf{1 4}$ were obtained from $\mathbf{1}$ following the same procedures used to obtain $\mathbf{1 1}$ and 12 from anticopalic acid methyl ester (10). The spectroscopic data of $\mathbf{1 3}$ and $\mathbf{1 4}$ were in full agreement with their proposed structures (see Materials and Methods).

Taking into account, that some clerodanes and labdane diterpenoids possess strong antifeedant activity (Gebbinck et al., 2002), we decided to evaluate the antifeedant activity of $\mathbf{1}$ and $\mathbf{2}$. The results showed that $\mathbf{1}$ is more active than $\mathbf{2}$ (Table I), since the only difference between $\mathbf{1}$ and $\mathbf{2}$ is the presence of a $\beta$-orientated hydroxy group at $\mathrm{C}-3$ in the later; the absence of this moiety at C-3 is important to increase the activity.

None of the derivatives tested were more active than 1 (Table I). These results, also, indicated that slight changes in the chemical structure of 1 decrease the activity. For example, anticopalic acid methyl ester (10) was inactive, although its epoxide $\mathbf{1 1}$ and $7 \alpha$-hydroxyanticopalic acid methyl ester (12) showed a moderate activity. The inclusion of an epoxy group at C-8/C-17, like in $\mathbf{1 3}$ or 
a $7 \alpha$-hydroxy moiety, like in $\mathbf{1 4}$ in $\mathbf{1}$ accomplished the increase of the activity of the derivatives.

None of the derivatives 10-14 were more active than the original diterpene $\mathbf{1}$, which showed an excellent antifeedant activity $\left(\mathrm{IC}_{50}=90.6 \mathrm{ppm}\right)$ against $S$. frugiperda indicating its potential use as antifeedant agent. It is worth to note, that this is the first report on a labdane-type diterpene active against $S$. frugiperda, as well as the first phytochemical study on Vitex hemsleyi.

Arndt F., Noller C. R., and Bergsteinsson I. (1946), Diazomethane. Organic Syntheses. Collective Vol. II. John Wiley \& Sons, New York, pp. 165-167.

Azhar-ul-Haq, Malik A., Khan M. T. H., Anwar-ul-Haq, Khan S. B., Ahmad A., and Choudhary M. I. (2006), Tyrosinase inhibitory lignans from the methanol extract of the roots of Vitex negundo Linn. and their structure-activity relationship. Phytomedicine 13, 255-260.

Céspedes C. L., Calderón J. S., Lina L., and Aranda E. (2000), Growth inhibitory effects on fall armyworm Spodoptera frugiperda of some limonoids isolated from Cedrela spp. (Meliaceae). J. Agric. Food Chem. 48, 1903-1908.

Cifuente D. A., Borkowski E. J., Sosa M. E., Gianello J. C., Giordano O. S., and Tonn C. E. (2002), Clerodane diterpenes from Baccharis sagitalis: insect antifeedant activity. Phytochemistry 61, 899-905.

Dharmasiri M. G., Jayakody J. R. A. C., Galhena G., Liyanaje S. S. P., and Ratnasooriya W. D. (2003), Anti-inflammatory and analgesic activities of mature fresh leaves of Vitex negundo. J. Ethnopharmacol. 87, 199-206.

Díaz F., Chávez D., Lee D., Mi Q., Chai H., Tan G. T., Kardono L. B. S., Riswan S., Fairchild C. R., Wild R., Farnsworth N. R., Cordell G. A., Pezzuto J. M., and Kinghorn D. (2003), Cytotoxic flavone analogs of vitexicarpin, a constituent of the leaves of Vitex negundo. J. Nat. Prod. 66, 865-867.

Dirzo R. and Carrasco V. (2002), Variación Interespecífica en la Herbivoría en Plantas de Fenología Constrastante en la Selva Baja de Huautla. Universidad Nacional Autónoma de México, México D.F., p. 36.

Fukushima J.-I., Yatagai M., and Ohira T. (2001), Abietane-type and labdane-type diterpenoids from the cones of Chamaecyparis obtuse. J. Wood Sci. 48, $326-330$.

Gebbinck E. A. K., Jansen B. J. M., and de Groot A. (2002), Insect antifeedant activity of clerodane diterpenes and related model compounds. Phytochemistry 61, 737-770.

González-Coloma A., Guadano A., Tonn C. E., and Sosa M. (2005), Antifeedant/insecticidal terpenes from Asteraceae and Labiatae species native to Argentinean semiarid lands. Z. Naturforsch. 60c, 855-861.

Harley R. M., Atkins S., Budantsev A., Cantino P. D., Conn B., Grayer R., Harley M. M., Kok R., de Krestovskaja T., Morales A., Paton A. J., Ryding O., and

\section{Acknowledgements}

C. V. G. appreciates the scholarship from Consejo Nacional de Ciencia y Tecnología (CONACYT) for her doctoral studies at Doctorado en Ciencias Biomédicas de la Universidad Nacional Autónoma de México. We are also grateful to Ms. Laura Patricia Lina García, UAEM, for technical assistance.

Upson T. (2004), Labiatae. In: The Families and Genera of Vascular Plants, Vol. VII (Kadereit J. W., ed.). Springer, Berlin, pp. 167-275.

Hugel G., Oehlschlager A. C., and Ourisson G. (1996), The structure and stereochemistry of diterpenes from Trachylobium verrucosum. Tetrahedron Suppl. 8 Part I, 203-216.

Kawazoe K., Yutani A., Tamemoto K., Yuasa S., Shibata H., Higuti T., and Takaishi Y. (2001), Phenylnaphthalene compounds from the subterranean part of Vitex rotundifolia and their antibacterial activity against methicillin-resistant Staphylococcus aureus. J. Nat. Prod. 64, 588-591.

Krishnarajah S. R., Ganesalingam V. K., and Senanayake U. M. (1985), Repellancy and toxicity of some plant oils and their terpene components to Sitotroga cerealella (Olivier) (Lepidoptera:Gelechiidae). Trop. Sci. 25, 249-252.

Ladeji O., Okoye Z. S. C., and Uddoh F. (1996), Effects of Vitex doniana stem bark extract on blood pressure. Phytother. Res. 10, 245-247.

Manh D. D. K., Bastard J., and Fétizon M. (1983), Plantes de Nouvelle-Caledonie. LXXVII. Diterpènes d'Agathis lanceolata. J. Nat. Prod. 46, 262-273.

Mazoir N., Benharref A., Bailén M., Reina M., and González-Coloma A. (2008), Bioactive triterpene derivates from latex of two Euphorbia species. Phytochemistry 69, 1328-1338.

Moreno-Osorio L., Cortés M., Armstrong V., Bailén M. and González-Coloma A. (2008), Antifeedant activity of some polygodial derivatives. Z. Naturforsch. 63c, $215-220$.

Paruch E., Katedra C., Akad R., and Wroclaw P. (2001), Natural and synthetic insect antifeedants. Part II. Wiad. Chem. 55, 119-149.

Reina M., González-Coloma A., Gutiérrez C., Cabrera R., Rodríguez M. L., Fajardo V., and Villarroel L. (2001), Defensive chemistry of Senecio miser Hook. J. Nat. Prod. 64, 6-11.

Sathiaoorthy B., Gupta P., Kumar M., Chaturvedi A. K., Shukla P. K., and Maurya R. (2007), New antifungal flavonoid glycoside from Vitex negundo. Bioorg. Med. Chem. Lett. 17, 239-242.

Seaman F. C. (1982), Sesquiterpene lactones as taxonomic characters in the Asteraceae. Bot. Rev. 48, $121-537$.

Shin T.-Y., Kim S.-H., Lim J.-P., Suh E.-S., Jeong H.-J., Kim B.-D., Park E.-J., Hwang W.-J., Rye D.-G., Baek 
S.-H., An N.-H., and Kim H.-M. (2000), Effect of Vitex rotundifolia on immediate-type allergic reaction. J. Ethnopharmacol. 72, 443-450.

Tawatsin A., Asavadachanukorn P., Thavara U., Wongsinkongman P., Bansidhi J., Boonruad T., Chavalittumrong P., Soonthornchareonnon N., Komalamisra N., and Mulla M. S. (2006), Repellency of essential oils extracted from plants in Thailand against four mosquito vectors (Diptera:Culicidae) and oviposition deterrent effects against Aedes aegypti (Diptera:Culicidae). Southeast Asian J. Trop. Med. Public Health 37, 915-931.

Umbreit M. A. and Sharpless K. B. (1977), Allylic oxidation of olefins by catalytic and stoichiometric selenium dioxide with tert-butylhydroperoxide. J. Am. Chem. Soc. 99, 5526-5528.
Walsingham L. and Atkins S. (2006), A new species of Vitex (Labiatae) from Tanzania. Kew Bull. 61, 615-617.

Webster D. E., Lu J., Chen S.-N., Farnsworth N. R., and Wang Z. J. (2006), Activation of the $\mu$-opiate receptor by Vitex agnus-castus methanol extracts: Implication for its use in PMS. J. Ethnopharmacol. 106, 216-221.

Woradulayapinij W., Soonthornchareonnon N., and Wiwat C. (2005), In vitro HIV tape 1 reverse transcriptase inhibitory activities of Thai medicinal plants and Canna indica L. rhizomes. J. Ethnopharmacol. 101, 84-89.

Zinkel D. F. and Spalding B. P. (1972), Anticopalic acid in Pinus strobus and P. monticola. Phytochemistry 11, 425-426.

Zinkel D. F. and Magee T. V. (1987), Diterpene resin acids from the needle oleoresin of Pinus strobus. Phytochemistry 26, 769-774. 